\title{
The Krever Commission - 10 years later
}

\section{Kumanan Wilson MD MSc}

$\mathrm{O}$ n Nov. 25, I997, Justice Horace Krever released his landmark report on how Canada's blood system managed the threat of HIV and hepatitis C transmission from blood transfusions. ${ }^{1}$ The tainted blood tragedy, as it came to be called, was arguably the largest public health catastrophe in this country's history. ${ }^{2}$ About Iooo individuals who received blood transfusions between the late-I970s and I980s were infected with HIV, and another 30000 were infected with hepatitis C. ${ }^{3}$ In 3 volumes, the Krever report meticulously described the events that led to this tragedy and provided guidance on how such a catastrophe could be avoided in the future.

One decade after the release of Krever's findings, the reform of the blood system should be viewed as a success particularly in terms of how Canadians are kept safe from bloodborne infections. The reformed blood system has regained public confidence and has even received high marks from the group representing the primary victims of the tainted blood tragedy. ${ }^{4}$ In retrospect, the findings of the Krever Commission could perhaps be considered the most influential report on public health in Canadian history. The report and the success of the reformed blood system provide important lessons related to public health.

\section{The importance of the Krever Commission}

First and foremost, the Krever Commission's set of 50 recommendations informed the creation and subsequent operation of a new national blood system. Anticipating the final report, federal, provincial and territorial government officials designed a plan for a national blood authority, leading to the creation of Canadian Blood Services, which replaced the Canadian Red Cross as the operator of the blood system. Quebec opted out of these discussions and developed its own blood system operated by HémaQuébec. ${ }^{5}$ However, the importance of the Krever Commission extends beyond the establishment of a new blood system. At a time when the attention of policy-makers was primarily devoted to our health care system, and when concerns about public health safety and infectious diseases were thought to be a thing of the past, the transmission of HIV and hepatitis C by blood transfusion served as a tragic reminder of these ongoing threats. The importance of our public health system's role in protecting Canadians' health $m$ emerges as a major theme from the Krever report. Consequently, many of the recommendations from the report to ensure blood safety transcend the blood system and have influenced many other areas. Two aspects of the reforms are particularly important: the institution of precautionary measures and the creation of a governance system that prioritizes safety.

\section{Key points of the article}

- The tainted blood tragedy was arguably the worst public health catastrophe in Canada's history.

- Guided by the Krever Commission findings, Canada's reformed blood system has restored public confidence in blood safety by proactively addressing infectious risks.

- Two influential concepts from the Krever Commission have contributed to the reformed blood system's success: the adoption of precautionary measures and the creation of a governance system with clearer roles and responsibilities, including the separation of funding from decision-making concerning safety.

\section{Precautionary measures}

Perhaps the most significant contribution of the Krever report to public health was its clarification of how evidence should be used to formulate policy with respect to blood safety. Before the report was released, a prominent criticism of decision-making in this regard was the reliance on high-level evidence as a pre-requisite for action to protect the public's health. Although it was highly effective in guiding clinical decision-making, Justice Krever identified this approach as clearly inappropriate for blood safety. In particular, Krever criticized the delays in implementing measures to protect the blood supply from HIV because of uncertainty about the magnitude of this threat and delaying the implementation of surrogate testing for hepatitis $\mathrm{C}$ until clear evidence of its efficacy was available from a randomized trial. ${ }^{3,6}$ Waiting for definitive evidence of risk resulted in the potentially avoidable exposure of thousands of individuals to tainted blood products. Krever stated that this approach was inconsistent with the public health ethos:

The slowness in taking appropriate measures to prevent the contamination of the blood supply was in large measure the result of the rejection, or at least the non-acceptance, of an important tenet in the philosophy of public health: action to reduce risk should not await scientific certainty. When there was reasonable evidence that serious infectious diseases could be transmitted by blood, the principal actors in the blood supply system in Canada refrained from taking essential preventive measures until causation had been proved with scientific certainty. The result was a national public health disaster. ${ }^{7}$

The reformed blood system has effectively incorporated Justice Krever's precautionary approach in addressing a series of potential infectious threats. At the time of its creation,

Kumanan Wilson is with the Department of Medicine, University of Toronto, Toronto, Ont. 
the new blood system was immediately confronted with the first of these threats: the theoretical risk of transmission of variant Creutzfeldt-Jakob disease. Despite the lack of clear evidence of transmission of the disease through blood transfusion, measures to protect the public against this risk were instituted, including deferring donations from individuals who had travelled to the United Kingdom during the peak of the "mad cow" outbreak. In retrospect the decision appears to be prescient. The transmission of variant CreutzfeldtJakob disease by blood transfusion has been confirmed and found to be an efficient mechanism for spreading the infection. ${ }^{8,9}$ The blood system responded in a similar way to the documentation of transmission of West Nile virus, first with recalls of potentially affected blood products and then with the introduction of a screening test for donors. ${ }^{10,11}$ During the severe acute respiratory syndrome (SARS) crisis, the blood system introduced precautionary measures in its screening process, such as deferring donations from individuals at risk of harbouring the virus, without waiting for evidence of transfusion transmission. ${ }^{12}$ Table i shows examples of infectious threats to the blood system and some of the policy responses, both before and after the system was reformed.

Although the precautionary approach had been an important concept in environmental policy, Justice Krever's report was highly influential in advocating for its application to public health. The concept has subsequently been widely adopted within public health and government riskmanagement practices. During the SARS outbreak, public health officials repeatedly called for precautionary measures to be adopted despite incomplete scientific information on the risk posed by the virus. In fact, Justice Archie Campbell's last report on the SARS outbreak in Ontario directly referred to Justice Krever's report when identifying the importance of incorporating precautionary decisionmaking to protect health worker safety. ${ }^{17}$ In addition, Canada's pandemic influenza planning process has been characterized by the need to take measures to protect against what is still a theoretical risk. In 2003, the federal government released a document describing how the precautionary approach should be used to guide all sciencebased risk decision-making. ${ }^{18}$

\section{Governance}

A second major contribution of the Krever Commission was its identification of the vital role of governance in ensuring safety in public health. ${ }^{13}$ The Krever report concluded that the structure of the previous blood system was flawed in at least 2 respects. First, the system was organized in a manner that allowed cost-considerations to affect decisions related to safety. Second, ambiguity over the roles and responsibilities of the various actors in the system created risks in the safety of blood products. The Krever report stated

In its report the safety audit committee concluded that responsibility for the blood system is fragmented ... the various functions integral to the supply of blood, such as regulation, funding and planning, are undertaken by different stakeholders. The respective functions, authority and accountability of each party are not well defined. ... This lack of definition may affect accountability within the system, and ultimately its safety. ${ }^{19}$

The new blood system was designed with these concerns in mind. Roles were clearly allocated to the new blood system actors. Canadian Blood Services was created as an armslength organization - a not-for-profit Crown corporation that must respond to federal regulations but that also has the authority to exceed them. The provinces' primary role was to fund Canadian Blood Services; however, the organization does not have to seek decision-by-decision funding approval from the provinces. By insulating the operator from financial consideration in this way, the reformed blood system has flexibility in the introduction of aggressive safety measures that might otherwise have encountered opposition from a funding organization concerned about the absence of clear evidence for their efficacy. ${ }^{20}$

Table 1: Examples of infectious disease threats to the blood system and related policy responses, pre- and post-reform

\begin{tabular}{lll}
\hline Infectious disease & Transfusion risk confirmed (yr) & Precautionary measure adopted (yr) \\
\hline $\begin{array}{l}\text { Old blood system } \\
\text { Hepatitis } C^{1}\end{array}$ & Confirmed (1974) & Hepatitis C antibody testing (1990) \\
\hline HIV $^{1}$ & Confirmed (1982) & HIV antibody testing (1985) \\
$\begin{array}{l}\text { Sporadic Creutzfeldt-Jakob } \\
\text { disease }\end{array}$ & Suspected but not confirmed (1987) & Product recall, donor deferral (1995) \\
$\begin{array}{l}\text { Reformed blood system } \\
\begin{array}{l}\text { Variant Creutzfeldt-Jakob } \\
\text { disease }\end{array}\end{array}$ & Highly probable (2004-2006) & \\
\hline $\begin{array}{l}\text { West Nile virus } \\
\text { 11 }\end{array}$ & Confirmed (2002) & Donor deferral (1998) \\
& & Product withdrawal (2002) \\
\hline SARS & & West Nile nucleic acid amplification \\
Chagas $^{15,16}$ & Suspected but not confirmed (2003) & Donor deferral (2003) \\
\hline
\end{tabular}

Note: SARS $=$ severe acute respiratory syndrome. 


\section{Consequences of blood system reform}

Any policy change has both advantages and disadvantages, and this is true for the post-Krever Commission blood system. A criticism of the new system, and of blood systems around the world, has been the overemphasis on rare, but high-profile, risks and lack of equivalent attention to less high-profile, but more common, risks, such as transfusion reactions. ${ }^{21}$ The adoption of the precautionary approach has partly contributed to a mentality that is highly averse to risk that has led to the introduction of some safety measures considered to be cost-ineffective, with costs per quality-adjusted life-years sometimes in the millions. ${ }^{22}$ Combined with difficulties in improving blood use, these safety measures have contributed to rising blood costs. ${ }^{23}$

These criticisms are valid and they were anticipated by Krever, who stated that the principle of safety being paramount would increase costs and affect blood supplies. Nevertheless, policies that may have been viewed as excessively erring on the side of safety were essential for a blood system that could not have sustained a mismanaged infectious disease threat so soon after its creation. Now that Canada has distanced itself from the tainted blood tragedy, and that public confidence in the blood system has been re-established, officials have the luxury of re-examining safety priorities and the correct balance between safety and cost.

\section{Learning from success}

Canada was not the only country affected by the transmission of hepatitis C and HIV through blood transfusion, and other nations' blood systems subsequently have aggressively promoted the institution of precautionary safety measures. For example, in an effort to prevent the transmission of variant Creutzfeldt-Jakob disease the United Kingdom has banned all donations from individuals who previously received a blood transfusion. ${ }^{24}$ Several European countries have implemented forms of pathogen inactivation systems to protect against both present and potential future transfusion infectious risks. ${ }^{25}$ And recently, the American Red Cross began screening their blood supply for Chagas disease. ${ }^{26}$

Canada's experience, however, was unique because of the extent of structural reform to the blood system. Although most other countries changed their approaches to blood safety, Canada created a new blood system. The Krever Commission was instrumental in guiding this transformation. The success of the subsequent blood system reform process and the adoption of the concepts in the report by other areas in public health speak to the importance of its findings. However, recommendations alone are not enough to successfully reform a broken system. Most important is the dedication, expertise and commitment of the individuals involved in acting upon the recommendations. The blood system has also been particularly well served in this respect.
Competing interests: Kumanan Wilson has received funding from the Public Health Agency of Canada for a study of intergovernmental relations in public health. He is also an unpaid member of the Ontario Blood Advisory Committee.

\section{REFERENCES}

I. Krever H. Final report: Commission of Inquiry on the Blood System in Canada. Ottawa: The Commission; I997.

2. Picard A. The gift of death: confronting Canada's tainted-blood tragedy. Toronto: HarperCollins; 1998.

3. Krever $\mathrm{H}$. The consequences of the contamination of the blood supply. In: Final report: Commission of Inquiry on the Blood System in Canada. Ottawa: The Commission; 1997. p. 708-I8.

4. Blood Safety Committee of the Canadian Hemophilia Society. Report card on Canada's blood system 7 years after the Commission of Inquiry on the Blood System in Canada. 2005. Available: www.hemophilia.ca/en/IO.I.4.php (accessed 2007 Oct I6).

5. Wilson K, Hebert PC, Laupacis A, et al. A policy analysis of major decisions relating to Creutzfeldt-Jakob disease and the blood supply. CMAJ 2001;165:59-65.

6. Krever H. Canada's rejection of surrogate testing. In: Final report: Commission of Inquiry on the Blood System in Canada. Ottawa: The Commission; 1997. p. 649-86.

7. Krever H. The blood supply system in Canada: systemic problems in the I98os. Commission of Inquiry on the Blood System in Canada. Final report. Ottawa: Canadian Government Publishing; I997;989.

8. Llewelyn CA, Hewitt PE, Knight RS, et al. Possible transmission of variant Creutzfeldt-Jakob disease by blood transfusion. Lancet 2004;363:417-2I.

9. Hewitt PE, Llewelyn CA, Mackenzie J, et al. Creutzfeldt-Jakob disease and blood transfusion: results of the UK Transfusion Medicine Epidemiological Review study. Vox Sang 2006;91:22I-30.

Io. Pealer LN, Marfin AA, Petersen LR, et al. Transmission of West Nile virus through blood transfusion in the United States in 2002. N Engl J Med 2003;349:1236-45.

II. Vamvakas EC, Kleinman S, Hume H, et al. The development of West Nile virus safety policies by Canadian blood services: guiding principles and a comparison between Canada and the United States. Transfus Med Rev 2006;20:97-Io9.

I2. News CBC. Blood agency takes precautions against SARS. 2003 Apr II. Available: www.cbc.ca/story/canada/national/2003/04/II/sars_bloodo304II.html (accessed 2007 Oct 16 ).

I3. Wilson K. Structural reform in the Canadian blood system. In: Beach CM, Chaykowski RP, Shortt S, et al, editors. Health services restructuring in Canada. New evidence and new directions. Kingston: McGill-Queen's University Press; 2006. p. 345-73.

I4. Wilson K, Graham I, Ricketts M, et al. Variant Creutzfeldt-Jakob disease and the Canadian blood system after the tainted blood tragedy. Soc Sci Med 2007;64:174-85.

I5. Comeau P. Canadian Blood Services to screen for Chagas disease. CMAJ 2007;177:242.

I6. Leiby DA, Herron RM Jr, Read EJ, et al. Trypanosoma cruzi in Los Angeles and Miami blood donors: impact of evolving donor demographics on seroprevalence and implications for transfusion transmission. Transfusion 2002;42:549-55.

I7. Campbell A. Recommendations. In: The SARS Commission final report. Spring of fear, volume 3. Toronto: Ontario Ministry of Health and Long-Term Care; 2006. p. II57-8. Available: www.sarscommission.ca/report/v3-pdf/Vol3 3 Chpg.pdf (accessed 2007 Oct I6).

I8. Government of Canada Privy Council Office. A framework for the application of precaution in science-based decision making about risk. Ottawa: Privy Council Office; 2003 .

I9. Krever $\mathrm{H}$. The initiatives of the federal, provincial and territorial governments to reform the blood system. Commission of Inquiry on the Blood System in Canada. Final report. Ottawa: Canadian Government Publishing; 1997;1023.

20. Wilson $\mathrm{K}, \mathrm{McC}$ rea-Logie J, Lazar $\mathrm{H}$. Understanding the impact of intergovernmental relations on public health: lessons form reform initiatives in the blood system and health surveillance. Can Public Policy 2004;30:177-94.

2I. AuBuchon J, Petz L. Making decisions to improve transfusion safety. In: AuBuchon J, Petz L, Fink A, editors. Policy alternatives in transfusion medicine. Bethesda (MD): AABB; 200I. p. I84-226.

22. van Hulst M, de Wolf JT, Staginnus U, et al. Pharmaco-economics of blood transfusion safety: review of the available evidence. Vox Sang 2002;83:I46-55

23. Wilson $\mathrm{K}$, Hebert PC. The challenge of an increasingly expensive blood system. CMAJ 2003;I68:II49-50.

24. Ludlam CA, Turner ML. Managing the risk of transmission of variant Creutzfeldt Jakob disease by blood products. Br J Haematol 2006;132:13-24.

25. Sandler SG. The case for pathogen inactivation of blood components. Curr Opin Hematol 2005;12:47I-2.

26. Centers for Disease Control and Prevention. Blood donor screening for chagas disease — United States, 2006-2007. MMWR Morb Mortal Wkly Rep 2007;56:I4I-3.

Correspondence to: Dr. Kumanan Wilson, I4EN-220, Toronto General Hospital, University Health Network, 200 Elizabeth St., Toronto ON M5G 2C4; fax 4 I6 595-5826;

kumanan.wilson@uhn.on.ca 